\title{
HUBUNGAN ANTARA IKLIM ORGANISASI DAN PENGETAHUAN KOMUNIKASI DENGAN PRESTASI KERJA PEGAWAI DINAS PENDIDIKAN KOTA DEPOK
}

\author{
IIN ASIKIN*
}

\begin{abstract}
This research aims to determine the relationship between: (1) organizational climate with achievement; (2) knowledge of communication with achievement; and (3) the relation between organizational climate and knowledge of communication with achievement. The research method using survey by correlation approach. This research used as a sample of 80 employees, and 20 employees for testing, and selected based on a simple random technique (simple random sampling). The study was conducted at Depok Local Office Education.Technique data collecting was using the instrument in the form of questionnaire. This instrument is calibrated with the test item validity and reliability coefficients. To test the validity of using Pearson Product Moment correlation, while the reliability coefficient is calculated using the formula of Cronbach Alpha.

The results showed that: first, there were positive relationship between organizational climate and achievement; secondly, there is a positive relationship between knowledge of communication with achievement; thirdly, there is a positive relationship between organizational climate and knowledge of communication together with achievement.The implication of this research is an effort in improving the achievement can be done through organizational climate and knowledge of communication.
\end{abstract}

Keywords: Organizational Climate, Knowledge of Communication, Achievement.

\section{PENDAHULUAN}

Pendidikan bertujuan menghasilkan tenaga terampil, berpengetahuan, berdisiplin dan memiliki motivasi dan kreativitas yang dibutuhkan dalam upaya peningkatan nilai-nilai kemanusiaan dan derajat kesejahteraan. Melalui pendidikan, manusia memiliki kesanggupan dan kemampuan dan kepekaan untuk menentukan alternatif paling menguntungkan dalam hidupnya. Disamping itu pendidikan memiliki daya perubahan kearah peningkatan kualitas kehidupan pribadi dan masyarakat. Tentu saja tergantung kepada daya kekuatan pendidikan dalam merespon perubahan nilainilai yang ada sesuai dengan tuntutan kebutuhan manusia. Untuk itu, salah satu pihak yang bertanggung jawab dalam pelaksanaan pendidikan di Indonesia adalah Dinas Pendidikan. Pada era sentralisasi, pemerintah daerah tidak pernah memikirkan semua tanggung jawab pelaksanaan pendidikan sampai rinci, karena semua perencanaan dilaksanakan oleh pemerintah pusat saat itu. Pemerintah Kabupaten atau Kota hanya berkewajiban untuk mengimplementasikan rencana yang disusun oleh Pemerintah Pusat berdasarkan kemampuan, fasilitas dan kondisi yang ada.

Namun, dengan telah diberlakukannya Undang-Undang tentang Pemerintahan Daerah Nomor 22 tahun 1999 yang kemudian pada tahun 2004 mengalami perubahan menjadi Undang-Undang Nomor 32 Tahun 2004, maka paradigma sistem pemerintahan yang semula terpusat atau sentralisasi berubah menjadi desentralisasi atau otonom pada tiap-tiap pemerintah daerah tingkat II (dua). Tujuan otonomi daerah adalah untuk memberikan kewenangan pada pemerintah daerah tingkat II (dua) untuk mengatur sistem pemerintahannya sendiri mengacu pada Negara kesatuan Republik Indonesia. Undang-Undang Nomor: 32 Tahun 2004 tentang

\footnotetext{
* Staf pengajar di Lembaga Pendidikan Primagama Depok
} 
Pemerintahan Daerah Pasal 10 ayat (1) dengan tegas menyatakan bahwa: Kewenangan daerah mencakup kewenangan dalam seluruh bidang pemerintahan kecuali kewenangan dalam bidang politik luar negeri, pertahanan keamanan, peradilan, moneter dan fiskal, agama serta kewenangan bidang lain.

Sebagaimana uraian diatas maka pemerintahan Kota Depok juga melaksanakan sistem pemerintahan desentralisasi dan otonom khususnya di bidang pendidikan yang dipimpin oleh seorang Kepala Kantor Dinas Pendidikan. Dengan adanya otonomi pendidikan, daerah dapat mengembangkan pendidikan yang diiperlukan diwilayahnya dengan mengacu pada standar pelayanan minimal yang diatur oleh pemerintah pusat.

Kinerja Pegawai Negeri Sipil (PNS) seringkali mendapat sorotan dari media massa dengan pemberitaan kinerja PNS yang buruk, hal ini tercermin dari para PNS yang dinilai kurang produktif, dan tidak disiplin serta berkinerja rendah. Untuk masalah ketidakdisiplinan, PNS kota Depok pernah mendapat sorotan dari pemberitaan Harian Pelita yang terbit pada tanggal 8 April 2011,dengan kedisiplinan yang makin menurun, jika keadaan tersebut dibiarkan begitu saja hal ini akan mempengaruhi tingkat pencapaian hasil kerja baik secara kuantitas maupun kualitas.

Untuk itu, apabila pegawai gagal berperan secara wajar dalam bekerja maka pimpinan wajib melakukan suatu analisis dan mencari penyebab dari masalah tersebut. Dengan menganalisis keadaan-keadaan yang terlihat dalam kinerja yang tidak memuaskan, seorang pimpinan dapat menggunakan strategi-strategi yang tepat untuk meningkatkan hasil kerja para karyawan agar dapat mencapai standar profesionalisme dalam mencapai tujuan organisasi.

Dinas Pendidikan Kota Depok sebagai salah satu pihak yang bertanggung jawab dalam pelaksanaan pendidikan dan dalam rangka mewujudkan otonomi pendidikan, membutuhkan sumber daya manusia yang memiliki prestasi kerja yang tinggi, serta berkualitas dan mampu mengelola organisasi dengan baik. Hal ini akan tercapai apabila para pegawai dapat memahami tugas atau kewajibannya sehingga mereka akan memiliki motivasi yang tinggi untuk bekerja dengan baik. Apalagi dengan adanya kebijakan Pemerintah Pusat dengan menaikkan gaji PNS mulai April 2011 , seperti diberitakan Sentana Online pada tanggal 11 April 2011, Pemerintah Kota Depok mengharapkan para pegawainya dapat meningkatkan kinerja seiring dengan kenaikan gaji tersebut. Untuk itu, perlu adanya perbaikan kinerja secara terus menerus pada pegawai Dinas Pendidikan Kota Depok, sehingga semua program pendidikan yang dikembangkan dapat terlaksana dan tujuan organisasi dapat dicapai.

Prestasi seorang pegawai bergantung pada keinginan berprestasi dan kemampuan yang bersangkutan untuk melakukannya. Motif berprestasi merupakan salah satu dari tiga motif pada diri manusia, menurut McClelland dalam Robbins, organisasi memberikan peluang kepada individu untuk memuaskan tiga macam kebutuhan, yaitu kebutuhan akan prestasi (the need for achievement), kebutuhan akan kekuasaan (the need for

power) dan kebutuhan akan kelompok atau pertemanan (the need for affiliation). Disebutkan bahwa kebutuhan berprestasi akan memberikan dorongan untuk lebih unggul, berprestasi

berdasarkan standar dan adanya usaha untuk bekerja keras demi mencapai kesuksesan.

Menciptakan sebuah iklim organisasi yang mampu membawa para anggotanya untuk meningkatkan prestasi dalam rangka pencapaian tujuan organisasi bukanlah suatu hal yang mudah. Hal ini disebabkan karena pada dasarnya manusia 
memiliki karakteristik tingkah laku yang berbeda sesuai dengan tingkat kebutuhannya. Apabila terdapat perbedaan atau kesenjangan antara persepsi anggota dengan persepsi pimpinan mengenai iklim yang dirasakan dan yang diharapkan, maka hal ini akan memungkinkan terciptanya ketidakpuasan kerja dari anggota, sehingga dapat menimbulkan penyalahgunaan hak dan kewajiban yang akhimya mengakibatkan tujuan organisasi tidak dapat dipenuhi secara optimal.

Iklim organisasi yang kondusif akan melahirkan persaingan yang sehat yang akan memacu orang untuk berprestasi. Untuk berprestasi, individu perlu menguasai semua hal yang terkait dengan bidang tugasnya dengan tetap menjaga standar moral untuk mendapatkannya, Dengan adanya suasana kerja sama antar pegawai yang tercipta dengan baik maka pegawai dapat saling membantu dalam pemecahan masalah, mengembangkan idenya masing-masing, dapat saling tukar menukar informasi dan saling berbagi pengetahuan dan keterampilan dalam melaksanakan tugas mereka. Untuk itulah diperlukan adanya pengetahuan komunikasi yang baik sehingga pikiran atau ide yang disampaikan akan dapat dipersepsikan penerima persis dengan yang dibayangkan oleh pengirim.

Dalam organisasi komunikasi menjadi begitu penting, karena melalui komunikasi yang baik orang bisa memindahkan ide ataupun mengendalikan perilaku bawahan. Melalui komunikasi yang tepat segala persoalan yang timbul dapat diselesaikan, seperti konflik, keresahan, kesalahpahaman dan sebagainya. Selain itu, Individu pada dasarnya sekitar 70 persen dari waktu kerjanya dipakai untuk berkomunikasi baik dalam bentuk menulis, membaca, berbicara serta mendengarkan. Oleh karena itu dapat dimengerti jika dikatakan bahwa salah satu penghalang terbesar dari kekuksesan prestasi organisasi adalah kurangnya komunikasi yang efektif.

Prestasi Kerja.Istilah prestasi kerja dalam Bahasa Inggris sepadan dengan kata performance atau achievement, kata tersebut digunakan untuk menyebutkan hasil yang telah dicapai seseorang atau sekelompok orang dalam melakukan suatu pekerjaan atau aktivitas tertentu. Adapula yang mengatakan kinerja sama dengan prestasi, karena kinerja berasal dari kata yang sama yaitu performance yang artinya sama dengan prestasi kerja.

Menurut Luthans, "achievement may be defined as the degree to which a person wishes to accomplish challenging goals, succeed in competitive situations, and exhibit the desire for unambiguous feedback regarding performance." Prestasi bisa didefinisikan sebagai tingkat dimana orang berharap menyelesaikan sasaran yang menantang, berhasil dalam suatu persaingan, dan menunjukkan keinginan untuk umpan balik yang jelas berkaitan dengan kinerja. Umpan balik diperlukan seseorang dalam rangka memantau perkembangan prestasi.

Schermerhorn mengatakan bahwa, "achievement is getting things done and working hard to accomplish difficult things in life." Prestasi adalah menyelesaikan pekerjaan dan bekerja keras untuk mencapai hal-hal yang sulit dalam kehidupan. Untuk mengatasi

berbagai hambatan maupun berbagai sasaran yang sulit, dibutuhkan kerja keras sehingga semua bisa dilalui dengan baik.

Selanjutnya, Ivancevich menyatakan bahwa, "achievement may be defined as the degree to which a person wishes to accomplish challenging goals, succeed in competitive situations." Prestasi dapat didefinisikan sebagai tingkat keinginan seseorang untuk mencapai tujuan yang menantang, dan berhasil dalam situasi yang kompetitif. Dalam 
mencapai tujuan yang menantang perlu didukung oleh sikap realistis terhadap kekuatan dalam diri, sehingga keberhasilan bisa dicapai dengan maksimal.

Prabowo mengemukakan bahwa "prestasi lebih merupakan tingkat keberhasilan yang dicapai seseorang untuk mengetahui sejauhmana seseorang mencapai prestasi yang diukur atau dinilai."

Suryabrata menyatakan bahwa "prestasi merupakan suatu hasil yang dicapai seseorang setelah ia melakukan suatu kegiatan."

Menurut Lawler dan Porter, "prestasi kerja merupakan hasil yang dicapai oleh karyawan dalam mengerjakan tugas atau pekerjaannya secara efisien dan efektif."

Prestasi berkenaaan dengan apa yang diinginkan dan mampu menetapkan tujuan yang hendak dicapai dan mampu melaksanakan seluruh rencana dengan mengatasi rintangan maupun kesulitan yang menghadang. Pada hakikatnya hanya pegawai yang bermotivasi tinggi yang menjalankan pekerjaannya mengungguli yang lain untuk mencapai kinerja dan keberhasilan.

Iklim Organisasi. Ivancevich, Konopaske dan Matteson berpendapat bahwa iklim organisasi adalah "a set of properties of the work environment, perceived directly or indirectly by the employees, that is assumed to be a major force in influencing employee behavior." (Seperangkat lingkungan kerja yang dirasakan secara langsung atau tidak langsung oleh para pegawai, serta diduga mempunyai pengaruh besar terhadap perilaku para pegawai). Lingkungan kerja yang dirasakan langsung maupun tidak langsung dapat berbentuk psikis seperti hubungan kerja antara karyawan dengan karyawan atau atasan dengan bawahan dan berbentuk suasana yang sifatnya fisik seperti: ruangan kerja, sirkulasi udara, kesejukan dan lain-lain.

Hal ini juga sejalan dengan pemikiran Lussier, bahwa "organizational climate is the relatively enduring quality of the internal environment of the organization as perceived by its members." Iklim organisasi merupakan suatu kondisi internal suatu organisasi yang dirasakan oleh anggota anggotanya.

Berdasarkan pendapat yang dikemukakan di atas ada beberapa unsur penting yang tercakup dalam pengertian iklim organisasi ini, pertama, iklim organisasi merupakan kondisi atau suasana yang dirasakan oleh anggota organisasi. Kedua, suasana tersebut tercipta dari hubungan antarpribadi anggota organisasi. Ketiga, suasana atau kondisi tersebut mempengaruhi perilaku anggota organisasi.

Iklim Organisasi tidak hanya memperlihatkan hubungan yang terjadi di dalam organisasi tetapi juga hubungan kepada pelanggannya. Hal ini dikatakan oleh Luthans, bahwa iklim organisasi "this is an over all feeling that is conveyed by the physical layout the way participants interact and the way members of the organization conduct themselves with costumer or other outsiders." Iklim organisasi merupakan keseluruhan perasaan yang disalurkan dengan cara anggota organisasi berperilaku terhadap pelanggan atau orang lain.

Sedangkan Menurut Robbins, "organizational climate refers to the shared perceptions organizational members have about their organization and work environment." Iklim organisasi berhubungan dengan persepsi anggota organisasi terhadap organisasi dan lingkungan kerjanya.

Menurut Michael A. West, iklim organisasi adalah suatu metafora yang menggambarkan agregat persepsi karyawan individual mengenai lingkungan 
organisasi mereka, suatu persepsi yang mempengaruhi motivasi, inovasi serta kinerja mereka.

Sejalan dengan itu Laurie J. Mullins menyatakan bahwa, "organizational climate is the employees perception of how it feels to work in the unit and includes specific aspects of the environment that directly affect people's ability to get the job done. A manager's efforts will have an effect on employees, ideally the creation of a productive organizational climate." Iklim organisasi adalah persepsi karyawan tentang bagaimana perasaannya dalam bekerja pada suatu unit kerja, dan meliputi aspek-aspek spesifik dari lingkungan yang mempengaruhi secara langsung kemampuan seseorang dalam melakukan pekerjaan.

Berdasarkan teori dan konsep di atas, dapat disintesiskan bahwa iklim organisasi adalah keadaan atau suasana lingkungan kerja yang dirasakan oleh pegawai yang tercipta dari hubungan antar pribadi dan dapat mempengaruhi perilaku para pegawai untuk dapat bekerja lebih maksimal dengan indikator : ketersediaan sarana dan fasilitas kerja, kebersamaan, hubungan kerja dan adanya kejelasan terhadap tugas

Pengetahuan Komunikasi. Buckley dan Carter berpendapat bahwa "pengetahuan merupakan informasi terstruktur yang mengungkap keterkaitan, wawasan dan generalisasi yang tidak dimiliki oleh informasi sederhana." Pendapat ini mengisyaratkan bahwa pengetahuan adalah hal yang berbeda dari data dan informasi meskipun masih juga terkait dengannya. Dalam organisasi, orang-orang yang berpengetahuan merupakan kekuatan utama dalam menghadapi berbagai rupa dan kecepatan perubahan di masa depan.

Menurut Bergeron "pengetahuan merupakan informasi yang telah diorganisasi, diseintesisikan, diringkaskan untuk meningkatkan pengertian, kesadaran atau pemahaman." Dengan demikian pengetahuan merupakan kombinasi informasi dan kesadaran atau pemahaman terhadap suatu konteks.

Marzano dan Kendall lebih memperjelas lagi tingkatan pengetahuan (ranah kognitif) dari Bloom sebagai berikut : (1) knowledge (pengetahuan) mencakup ingatan untuk mengungkapkan kembali hal-hal yang pernah dipelajari. (2) comprehension (pemahaman) mencakup kemampuan untuk mengungkapkan makna dan arti dari yang dipelajari. (3) application (penerapan) mencakup kemampuan untuk menerapkan suatu kaidah atau metode pada satu kasus yang konkrit (4) analysis (analisis) mencakup kemampuan untuk memerinci suatu kesatuan ke dalam bagian-bagian sehingga struktur keseluruhan dapat dipahami dengan baik. (5) syinthesis (sintesis) mencakup kemampuan untuk membentuk suatu kesatuan atau pola baru. (6) evaluation (evaluasi) mencakup kemampuan untuk membentuk satu pendapat dan mempertanggungjawabkannya berdasarkan kriteria tertentu.

Komunikasi menjadi bagian yang sangat penting dalam organisasi, karena penyampaian informasi yang akurat dan pemahaman atas informasi dari satu unit

(pengirim) ke unit lain (penerima) tidak hanya penting dalam perumusan dan implementasi tujuan organisasi. Melalui komunikasi yang efektif dalam organisasi maka pemimpin dapat mengetahui saran dan kebutuhan anggota organisasi. Sedangkan, pihak anggota organisasi dapat memahami pekerjaan mereka dengan baik, dapat melakukan koordinasi dengan pimpinan maupun dengan rekan kerja, sehingga tercipta rasa keterikatan dan loyalitas terhadap organisasi.

Berdasarkan teori dan konsep di atas, dapat disintesiskan bahwa pengetahuan komunikasi merupakan wawasan atau sesuatu yang diketahui seseorang berkaitan 
dengan aspek mengingat, memahami dan menerapkan berbagai berbagai konsep, proses, jaringan, hambatan dan efektivitas dalam berkomunikasi.

\section{METODE}

Metode penelitian yang digunakan pada penelitian ini adalah metode survey, dengan pendekatan korelasional. Penelitian ini dilaksanakan di Kantor Dinas Pendidikan Kota Depok. Populasi dalam penelitian ini adalah seluruh pegawai yang bertugas di Kantor Dinas Pendidikan Kota Depok. Populasi terjangkau pada penelitian ini adalah pegawai pada Kantor Dinas Pendidikan Kota Depok sebanyak 100 orang.

\section{HASIL PENELITIAN DAN PEMBAHASAN}

1. Hubungan antara iklim organisasi dengan prestasi kerja pegawai

Dari hasil analisis korelasi antara iklim organisasi dengan prestasi kerja pegawai, diperoleh koefisien korelasi sebesar 0,673 $\left(\mathrm{r}_{\mathrm{y} 1}=0,673\right)$. Nilai ini memberikan pengertian bahwa keterkaitan antara iklim organisasi dengan prestasi kerja pegawai adalah signifikan atau positif. Artinya, semakin tinggi tingkat iklim organisasi pegawai, akan semakin tinggi pula prestasi kerja pegawai tersebut. Sedangkan koefisien determinasi diperoleh dari kuadrat koefisien korelasi antara iklim organisasi $\left(\mathrm{X}_{1}\right)$ dan prestasi kerja pegawai ( $Y$ ) yaitu sebesar $\mathrm{r}_{\mathrm{y1}}{ }^{2}=0,673^{2}=0,45348$. Ini menunjukkan bahwa $45,348 \%$ prestasi kerja pegawai dapat ditentukan oleh iklim organisasi.

Selanjutnya untuk mengetahui keeratan hubungan antara iklim organisasi $\left(\mathrm{x}_{1}\right)$ dengan prestasi kerja pegawai (Y) secara parsial, perlu dilakukan pengontrolan pengaruh variabel pengetahuan komunikasi $\left(\mathrm{X}_{2}\right)$ terhadap prestasi kerja pegawai $(\mathrm{Y})$ dengan koefisien korelasi parsial $=0,350$. Setelah dikontrol variabel pengetahuan komunikasi $\left(X_{2}\right)$, menunjukkan bahwa hubungan antara iklim organisasi $\left(X_{1}\right)$ dengan prestasi kerja pegawai $(\mathrm{Y})$ adalah menunjukkan hubungan yang tetap positif dan sangat signifikan pada taraf $\alpha=0,01$.

Hasil penelitian ini sejalan Mullins menyatakan bahwa "Climate will influences the attitudes which members of the organizations bring to bear on their work performance and personal relationships." Iklim akan berpengaruh terhadap sikap anggota organisasi yang berdampak pada prestasi kerja mereka dan hubungan antar pribadi. Oleh karena iklim organisasi merujuk kepada berfungsinya organisasi dan secara keseluruhan berdasarkan persepsi karyawan mengenai lingkungan organisasi mereka dan persepsi tersebut mempengaruhi

hubungan antar pribadi dan prestasi kerja mereka, maka apabila menurut persepsi mereka iklim organisasi yang ada kondusif atau menyenangkan hal tersebut akan mendorong mereka untuk melakukan tugas dengan lebih baik dan bertanggung jawab

sehingga tercapai keberhasilan dalam mencapai prestasi kerja yang optimal sesuai dengan kemampuannya.

\section{Hubungan antara pengetahuan komunikasi dengan prestasi kerja pegawai}

Dari hasil analisis korelasi pengetahuan komunikasi dengan prestasi kerja pegawai, diperoleh koefisien korelasi sebesar 0,649 $\left(\mathrm{r}_{\mathrm{y} 2}=0,649\right)$. Nilai ini memberikan pengertian bahwa keterkaitan antara pengetahuan komunikasi dengan prestasi kerja pegawai adalah signifikan atau positif. Artinya, semakin tinggi tingkat pengetahuan komunikasi pegawai, akan semakin tinggi pula prestasi kerja pegawai tersebut. Sedangkan koefisien determinasi diperoleh dari kuadrat koefisien korelasi antara pengetahuan komunikasi $\left(\mathrm{X}_{2}\right)$ dan prestasi kerja pegawai $(\mathrm{Y})$ yaitu sebesar $\mathrm{r}_{\mathrm{y} 2^{2}}=0,6492$ 
$=0,42067$. Ini menunjukkan bahwa 42,067\% prestasi kerja pegawai dapat ditentukan oleh pengetahuan komunikasi.

Selanjutnya untuk mengetahui keeratan hubungan antara pengetahuan komunikasi $\left(\mathrm{X}_{2}\right)$ dengan prestasi kerja pegawai $(\mathrm{Y})$ secara parsial, perlu dilakukan pengontrolan pengaruh variabel iklim organisasi $\left(X_{1}\right)$ terhadap prestasi kerja pegawai $(Y)$ dengan koefisien korelasi parsial $=0,264$. Setelah dikontrol variabel iklim organisasi $\left(\mathrm{X}_{1}\right)$, menunjukkan bahwa hubungan antara pengetahuan komunikasi $\left(\mathrm{X}_{2}\right)$ dengan prestasi kerja pegawai $(\mathrm{Y})$ adalah menunjukkan hubungan yang tetap positif dan sangat signifikan pada taraf $\alpha=0,01$.

Hasil penelitian ini selaras dengan pendapat Gibson et al. menyatakan bahwa, "the desired result of any employee's behavior is excellent performance. In organizations, therefore, individual and environmental variables affect not only behavior but also performance." Hasil yang diinginkan dari perilaku setiap pegawai adalah prestasi yang terbaik. Oleh karena itu, di dalam organisasi, variabel individu dan lingkungan mempengaruhi tidak hanya perilaku tetapi juga prestasi. Untuk itu variabel the environment (lingkungan) dan variabel the individual (individu) yang terdiri dari faktor abilities (kemampuan) yang dapat berupa pengetahuan, mempengaruhi tidak hanya behaviors (perilaku) berupa faktor komunikasi akan tetapi juga mempengaruhi variabel outcomes (hasil) berupa prestasi.

\section{Hubungan antara iklim organisasi dan pengetahuan komunikasi dengan prestasi kerja pegawai}

Dari hasil korelasi ganda antara iklim organisasi dan pengetahuan komunikasi secara bersama-sama dengan prestasi, diperoleh koefisien korelasi ganda sebesar 0,783 $\left(\mathrm{r}_{\mathrm{y} 12}=0,783\right)$. Nilai ini menunjukkan bahwa keterkaitan antara iklim organisasi dan pengetahuan komunikasi secara bersama-sama dengan prestasi kerja pegawai adalah signifikan atau positif. Artinya, semakin tinggi tingkat iklim organisasi dan semakin tinggi tingkat pengetahuan komunikasi pegawai, akan diikuti dengan semakin tingginya prestasi kerja pegawai tersebut. Dari koefisien korelasi ganda di atas, diperoleh koefisien determinasi hubungan antara iklim organisasi $\left(X_{1}\right)$ dan pengetahuan komunikasi $\left(\mathrm{X}_{2}\right)$ secara bersama-sama dengan prestasi kerja pegawai $(\mathrm{Y})$ sebesar $(0,783)^{2}$ $=0,6138$. Hal ini

menunjukkan $61,38 \%$ variasi variabel prestasi kerja $(\mathrm{Y})$ dapat dijelaskan oleh variabel iklim organisasi $\left(\mathrm{X}_{1}\right)$ dan pengetahuan komunikasi $\left(\mathrm{X}_{2}\right)$.

Besarnya sumbangan atau kontribusi variabel iklim organisasi dan pengetahuan komunikasi secara bersama-sama terhadap prestasi kerja pegawai dapat diketahui melalui nilai koefisien determinasi. Hasil analisis tersebut menunjukkan bahwa, kurang lebih dengan nilai koefisien determinasi, variasi prestasi kerja pegawai ditentukan/dijelaskan oleh iklim organisasi dan pengetahuan komunikasi secara bersama-sama dengan pola hubungan fungsionalnya seperti yang ditunjukkan oleh persamaan regresi.

Temuan ini sesuai dengan teori yang mengatakan bahwa terdapat hubungan secara bersama-sama antara iklim organisasi dan pengetahuan komunikasi dengan prestasi kerja.

Through communication, people exchange and share information with one another, and influence one another's attitudes, behaviors, and understandings. Communication allows managers to establish and maintain interpersonal relationships, listen to others, deal with 
conflicts, negotiate, and otherwise gain the information needed to create high performance workplace.

Melalui komunikasi orang saling bertukar dan berbagi informasi satu sama lain dan saling memengaruhi sikap, perilaku dan pemahaman. Komunikasi memungkinkan manajer untuk menciptakan dan memelihara hubungan antarpribadi, mendengar pihak lain, menangani konflik, bernegosiasi, dan jika tidak dia dapat memperoleh informasi yang dibutuhkan untuk menciptakan tempat kerja dengan kinerja/prestasi tinggi.

Berdasarkan pendapat tersebut di atas, dapat dijelaskan bahwa salah satu cara untuk menciptakan para pegawai dengan kinerja atau prestasi tinggi adalah dengan menciptakan dan memelihara hubungan antarpribadi yang harmonis, dimana hal tersebut merupakan bagian dari upaya membuat iklim organisasi menjadi kondusif, tentu saja hal ini akan terwujud jika di dukung oleh pengetahuan komunikasi yang baik sehingga Keefektifan dalam proses komunikasi akan terwujud. Melalui komunikasi yang efektif memungkinkan pimpinan untuk memotivasi para pegawai untuk bekerja sama dan memiliki tanggung jawab penuh serta memiliki komitmen yang tinggi dalam upaya mewujudkan keberhasilan dalam menjalankan tugas.

\section{PENUTUP}

Kesimpulan. Pertama, terdapat hubungan positif antara iklim organisasi dengan prestasi kerja pegawai, yang ditentukan oleh derajat kekuatan hubungan dalam bentuk koefisien korelasi dan koefisien determinasi. Kedua, terdapat hubungan positif antara pengetahuan komunikasi dengan prestasi kerja pegawai, yang ditentukan oleh derajat kekuatan hubungan dalam bentuk koefisien korelasi dan koefisien determinasi. Ketiga, terdapat hubungan positif antara iklim organisasi dan pengetahuan komunikasi secara bersama-sama dengan prestasi kerja pegawai, yang ditentukan oleh derajat kekuatan hubungan dalam bentuk koefisien korelasi ganda dan koefisien determinasi jamak.

Implikasi. Bertitik tolak dari hasil temuan di atas, maka implikasi hasil penelitian ini akan diarahkan kepada, 1) Upaya meningkatkan prestasi kerja melalui iklim organisasi, Hasil

penelitian ini menunjukkan bahwa prestasi kerja akan meningkat jika didukung oleh iklim organisasi yang kondusif. 2) Upaya meningkatkan prestasi kerja melalui pengetahuan

komunikasi, Aspek pengetahuan komunikasi merupakan salah satu unsur yang penting dalam upaya meningkatkan prestasi kerja pegawai.

Saran. Pertama, pimpinan Dinas Pendidikan Kota Depok perlu menciptakan iklim kerja yang lebih kondusif agar dapat meningkatkan prestasi kerja pegawai dengan memperhatikan harapan-harapan karyawan, demokratis, membina hubungan yang harmonis dan luwes. Kedua, Pegawai Dinas Pendidikan Kota Depok hendaknya lebih meningkatkan pengetahuan di bidang komunikasi melalui pelatihan- pelatihan yang relevan dengan kebutuhan aktivitasnya agar terjadi sinkronisasi antara pengetahuan komunikasi yang diperoleh dengan penyelesaian tugas. Ketiga, Dinas Pendidikan Kota Depok hendaknya menerapkan budaya membaca dengan menyediakan fasilitas berupa ruang perpustakaan dengan buku-buku yang relevan dengan pemberdayaan sumber daya yang terkait di sekitar lingkungan dinas pendidikan. Keempat, bagi pegawai Dinas Pendidikan Kota Depok hendaknya memperhatikan dan merespon aktif kesempatan dan peluang- peluang yang diberikan pimpinan, menjaga kepercayaan yang telah 
diberikan pimpinan, taat dan patuh terhadap peraturan organisasi yang telah menjadi komitmen bersama. Kelima, para peneliti terkait dengan hasil penelitian ini, agar melibatkan lebih banyak variabel prediktor yang diduga berkorelasi positif dengan prestasi kerja pegawai.

\section{DAFTAR RUJUKAN}

Ardana Komang ,Ni Wayan Mujiati, dan Anak Agung Ayu Sriathi, Perilaku Keorganisasian, Graha Ilmu: Yogyakarta, 2008

Ivancevich, Konopaske, and Matteson, Organizational Behavior and Management, Eight Edition (New York: McGraw-Hill,2008.

Lussier Robert N, Human relations in organizations, New York: McGraw Hill-Irwin, 2008. Luthans Fred, Organizational Behavior , New York: McGraw-Hill,2008

Michael A. West, Mengembangkan Kreativitas dalam Organisasi, Kanisius: Yogyakarta, 2004.

Muluk Khairul, Knowledge Management, Malang: Bayumedia Publishing, 2008

Robbins, Stephen P, Perilaku organisasi, Jakarta : Indeks Gramedia, 2006.

Robbins Stephen P. and Mary Coulter, Management, Tenth Edition, New Jersey: Pearson Prentice Hall, 2009.

Robert J. Marzano and John S. Kendall, Taxonomy of Educational Objectives,

California: Corwin Press, 2007.

Sangkala, Knowledge Management, Jakarta: PT Rajagrafindo Persada, 2007

Schermerhorn John R., Introduction to Management, Tenth Edition, River Street, Hoboken : John Wiley \& Sons, 2010.

Siregar, Kamus Indonesia- Inggris Lengkap, Jakarta: PT Aksara Binacendekia, 1990.

Wibowo, Manajemen Kinerja, Jakarta: Rajagrafindo Persada, 2010.

Umam Khaerul , Perilaku Organisasi, Bandung: Pustaka Setia, 2010. 